could continue only for a few weeks if no action was taken.

Following this outcry, the contractor responsible for the Nevada and Washington sites announced that they would be reopened to receive laboratory wastes. However, the South Carolina site remains closed, and the two west-coast sites are being used by all major research laboratories which have not been able to obtain a licence for disposing of radioactive materials by other means.

Now NRC is proposing that liquid scintillation media and animal carcases containing less than $\mu 0.05 \mathrm{Ci}$ of tritium or carbon-14 per gramme can be disposed of merely as toxic chemicals "without regard to their radioactivity".

The commission says that, since the potential dose to any individual exposed to these wastes would be less than 1 mrem a year, such a move would have a negligible effect on health aspects.

Using the same reasoning, it is also proposing that research laboratories and hospitals should be allowed to release up to $5 \mathrm{Ci}$ of tritium and $1 \mathrm{Ci}$ of carbon-14 a year into the sanitary sewage system, in addition to the present limit of $1 \mathrm{Ci}$ per year for all radionuclides.

If these changes are approved, the commission estimates that research institutions and hospitals will save up to $\$ 13$ million a year. Disposal of the wastes by more conventional means would cost only $\$ 3$ million a year, compared with the $\$ 16$ million it now costs to package and ship the materials to the west coast sites.

The proposed change in the rules is intended to conserve waste burial capacity that is already in short supply at nuclear dumps. At present, between 200,000 and 400,000 gallons a year of liquid scintillation media - mainly toluene containing heavily diluted radioactive tracers - has to be stored at these sites, taking up 400,000 cubic feet of space, with animal carcases taking up another 70,000 cubic feet.

Many university safety officers have welcomed the proposed changes in the rules. Others, however, are being more cautious, pointing out that the material will still have to be disposed of under strict federal, state and local regulations. Liquid scintillation media such as toluene are highly flammable and potentially carcinogenic - one of the reasons that South Carolina decided it notonger wanted to handle the wastes - and pose chemical and biological hazards which NRC says are a greater health problem than their radioactivity.

The result is that disposal will have to be carried out under strict new laws to deal with toxic wastes in general, such as the Resource Conservation and Recovery Act. The Environmental Protection Agency, however, has still to agree on how it intends to carry out the requirements of the act, and research laboratories are consequently uncertain of the new demands that they may have to meet.

David Dickson

\section{Soviet cosmonautics}

\section{Cuban went up}

All the most interesting aspects of Cuban science have been reflected in the SovietCuban space mission, according to Wilfredo Torres Yribar, President of the Cuban Academy of Sciences. Half of the 20 experiments planned for the flight, he said, reflect the interests of the Cuban economy.

Although space research began in Cuba " "just five years after the victory of the revolution", Yribar admitted that the initial contribution had been "rather modest". In the beginning, he said, space research had not even come under the Academy of Sciences, but had been supervised by the Ministry of Communications. However, for the past ten years, Cuba had been making extensive use of data from meteorological satellites. At first this was only for weather forecasting, but now, he said, the Meteorological Institute was working out programmes for monitoring industrial pollution and studying the influence of the earth's climate on the ripening of sugar cane.

Many of the experiments performed in orbit by Cuban cosmonaut Arnaldo Tamayo Mendez and his Soviet crew-mate Yurii Romanenko, appear to be simple extensions of the regular Salyut programme. As usual, there was an experiment to grow semiconductor materials using the Soviet-designed Splav furnace, while Cuba, as the non-Soviet participant, provided the experimental capsule - in this case, the target substance was epitaxial aluminium-doped gallium arsenide - and an appropriate code-name "Caribba".

The MKF-6 camera and the Bulgarianmade Spektr-15 apparatus (so named because it can record 15 radiation channels) have been standard equipment on several Salyut missions, although on this occasion they were used in the "Tropika" experiment (photography and field observations of a defined area of Cuba) and in "Antilla" - an examination of the dynamics of the physical, chemical and biological characteristics of agricultural land and part of the surrounding seas.

Medical experiments, too, are a regular part of such missions. In this case, they included a Cuban-designed "coordinograph", which determined the accuracy and time characteristics of the cosmonauts' coordination of right and left arm movements. Another new medical experiment, "Cortex", was described by the Cuban back-up cosmonaut Jose Lopez Falcon on Moscow radio: the cosmonauts, he said, are fitted with bonnets which include sensors and electrodes; light and sound signals are transmitted, and the data recorded.

The most specifically "Cuban" experiments, however, were "Sakhar' and

\section{Forgotten martyrs}

Perhaps the most interesting aspect of the Mendez-Romanenko flight is the light it throws on the early days of Soviet space research. Speaking last week on the twentieth anniversary of the Committees for the Defence of the Revolution, Fidel Castro paid tribute to the "scores of Soviet cosmonauts" who had paved the way for the Cuban flight. In particular, he recalled the "many who had died in their attempt to go into space or during their descent from space".

Those who died during descent are well known: Komarov in 1967 and the three crew-members of Soyuz 11 Dobrovol'skii, Volkov and Patsaev - in 1971. It is less clear who he meant by those who died attempting to go into space. Yurii Gagarin died in a plane crash in 1968, while still officially on the space team, and a back-up cosmonaut, Seregin, was killed with him. Two other trainee cosmonauts are believed to have perished in high-altitude training missions. The Soviet space planners have always been highly reticent about such accidents, and the rumours of the early 1960s often complete with cosmonauts' names and family details, seem for the most part to have had little or no foundation. Even Gagarin's historic flight was rumoured to have been the back-up mission to a disaster the previous day - a story which seems to have been generated by a premature TASS announcement although no signs of any launch were picked up by the US monitoring stations in orbit. (Just conceivably, of course, a spacecraft could have blown up on the launch pad.)

Castro referred to having visited a "gallery of martyrs" at, presumably, Baikonur, where he observed that the loss of life had been "relatively high" before space flights were "made safer". Since no westerner - except possibly Charles de Gaulle - has ever visited this gallery, Castro's remarks have renewed speculation as to just whom it commemorates.

"Zona". These are designed to study the growth of sugar monocrystals in conditions of weightlessness - the first time an attempt has been made to crystallize an organic substance in orbit. Also of Cuban provenance is the "Support"' experiment, which uses special Cuban-designed shoes that place a given load on the support areas of the feet. Returning cosmonauts, it seems, have a tendency to platypodia, and "Support" was intended to determine whether this change in the arch of the foot was a significant factor in post-flight posture disturbance. Although only Mendez wore the shoes on this occasion, they are to be worn by Soviet cosmonauts on future flights.

Vera Rich 